\title{
The Theory of Balance-of-Payments Adjustment: Comment
}

\section{Citation}

Cooper, Richard N. 1967. “The Theory of Balance-of-Payments Adjustment: Comment." J POLIT ECON 75 (S4) (January): 540. doi:10.1086/259329.

\section{Published Version}

doi:10.1086/259329

\section{Permanent link}

http://nrs.harvard.edu/urn-3:HUL.InstRepos:13580988

\section{Terms of Use}

This article was downloaded from Harvard University's DASH repository, and is made available under the terms and conditions applicable to Other Posted Material, as set forth at http:// nrs.harvard.edu/urn-3:HUL.InstRepos:dash.current.terms-of-use\#LAA

\section{Share Your Story}

The Harvard community has made this article openly available.

Please share how this access benefits you. Submit a story.

\section{Accessibility}




\section{COMMENT}

\section{RICHARD N. COOPER}

Yale University

$\mathrm{T}$ HE adjustment process used to be described in theoretical literature in terms of an automatic mechanism. This automaticity is largely (but not wholly) absent today, and discussion of this issue is better framed in terms of (1) when national policy makers should take measures to eliminate imbalances; (2) what measures are most appropriate and under what circumstances; and (3) what the division of responsibility should be among countries, for when there are any imbalances there must be at least two.

The first of these questions, when national policy makers should take measures to eliminate imbalances, is not usually asked explicitly, although it arises frequently enough in practice. It is not self-evident that imbalances always ought to be eliminated as quickly as possible; on the contrary, there will be many occasions in which rapid adjustment is costly to surplus or deficit country, and the best course of action is compensatory finance from surplus to deficit country. The lending facilities of the IMF offer one source of such finance; and national reserves can be used for the same purpose. Emminger points to the practical difficulties of making a correct assessment.

If it is decided that an imbalance should be eliminated, a variety of measures are at hand, none of them satisfactory as devices for general use in all cases. If changes in exchange rates are to be avoided, they come down basically to reductions in domestic demand (or increases by countries in surplus), restrictions on international transactions (or removal of restrictions by countries in surplus), and exhortations or stronger measures to improve the competitiveness of a country's products in world markets.

Both Scitovsky and Emminger turn to interregional payments adjustment within a country for enlightenment on how the process might work smoothly, effortlessly, and, it would seem, painlessly. In search of the solution to this riddle, Scitovsky focuses on the ready acceptability of regional financial assets in the national capital market. So long as a region holds such assets-indeed, so long as its credit is good-the region can finance its deficit by sale of financial claims. It would seem to avoid the hard choice among alternatives mentioned above.

In fact, interregional adjustment even in a country with a well-developed national capital market probably involves far more pain than Scitovsky's analysis implies, and in particular it involves substantial deflation in deficit regions, substantial inflation in surplus regions. "Depressed areas" are a familiar phenomenon in most countries. This term is itself ambiguous. Sometimes it means simply an area which is backward by modern standards. But more often it also means an area in which average incomes are low in part because workers and plant are idle or only partially employed. Whenever such areas have higher than average unemployment levels, depression is a manifestation of an ex ante regional balance-of-payments deficit at full employment. Depressed incomes and employment prevent the deficit from materializing. Sales of assets outside the region merely help to cushion the fall in economic activity; and if it persists, the movement of capital may even become perverse, capital moving out of the region and inducing further depression.

On the other hand, surplus areas experience expansion which spills rapidly over in to imports from other regions. This expansion will result in an "inflation" of factor incomes and other local costs even if price increases are limited by stiff import competition.

Why is this reliance on Keynesian income adjustments tolerated by regions within a country but not between countries? There are, I think, three reasons:

1. There is the absence of perception. 
Residents of a region typically do not think in terms of macroeconomic policy for their region. They cannot control their own money supply, and the possibilities for effective fiscal policy within the region are limited by the region's ability to borrow outside. The limited possibilities for pursuing regional stabilization policy limit the demands for action.

2. Deflation within a region is cushioned by transfers from the national government, as both Scitovsky and Emminger point out. Some of these are automatic. Regional tax payments linked to income decline as incomes decline, whereas, in contrast, national expenditure within the region presumably will not decline and may actually increase in the form of unemployment compensation, relief payments, and the like. Furthermore, national governments increasingly pursue deliberate regional policies, designed to stimulate activity within depressed regions through direct government expenditures, tax incentives to outside investment, and so on. On both counts the depressed region receives outside financing which helps prevent incomes from falling to the full extent required for elimination of the ex ante deficit.

3. Factor mobility from the region to other parts of the country will help cushion the welfare impact of regional deflation on the mobile factors. These factors can limit their losses by moving elsewhere. This is most true, of course, for financial capital, but it is also true for the young and the skilled members of the labor force. This fact of mobility, incidentally, reduces interest in the region by some of its potentially most articulate members.

Emminger adds one further important point, namely, that the very absence of independent regional monetary policy is a factor favorable to maintaining interregional equilibrium. This is unquestionably true, but it is only the obverse of what has been said above; regions cannot readily and do not typically pursue regional stabilization policies, but rather suffer the deflation or inflation required to restore and preserve balance. In short, they tolerate and accept a state of affairs which is not accepted by nations.

Let us return to the international case in which the participants typically manage their economies with an eye to overall domestic macroeconomic objectives as well as to international balance. Emminger points out that the cure for international imbalance must typically be related to its cause or diagnosis. He gives the example of overexpansion of domestic demand, which can lead both to an excess demand reflected in abnormally high imports and, with time, to a deterioration in the cost-competitiveness of the country's products at home and in world markets. There is a crucial difference between a deficit which can be eliminated simply by reducing domestic expenditures and one where costs have gotten so far out of line that some internal or external change in the country's price level will ultimately be required.

While Emminger is right in some sense, and his illustration is apt, I would prefer to formulate this question differently. In logic the cause is irrelevant to the proper remedy. The appropriate cure for international imbalance should be related not to the cause of the imbalance but to deviations from other policy targets (in the sense in which Tinbergen [1952] has used this term). Very often the "cause" of an imbalance will be reflected in deviations from other policy targets, and, hence, in these cases the cause should affect the cure. But there will be many cases in which the cause and the appropriate cure are unrelated. Here a choice must be made among national objectives. Policies to restore overall imbalance should be selected on the basis of a national (and international) cost-benefit calculation, not on the basis of the cause.

One of the key practical problems of an effective adjustment process is how to get surplus countries to adjust. I only halffacetiously suggest that this is even more difficult than getting reserve currency countries to adjust. Under the gold standard system adjustment was symmetrical. Countries 
in deficit experienced a deflation of monetary demand, but countries in surplus had an automatic inflation of monetary demand. These days that process has been largely broken on both sides (although in the past few years some surplus countries have acquiesced in some inflation). Deficit countries can ultimately be forced to adjust, since they will run out of reserves and financing can be withheld from them. No such sanction exists for surplus countries. France, for example, had a surplus for the seven years 1959-65, a surplus roughly twice as large in terms of GNP as the U.S. deficit. Germany's surplus lasted more than a decade, although it became more moderate in 1961-65, and in 1965 Germany even ran a deficit. Italy had a truly enormous surplus for the three years 1964-66, a surplus due in large part to deficient demand in the domestic economy. Stimulation of demand would not only reduce idle resources there but would also work toward external bal. ance. Yet Italy received far less pressure to reduce this large surplus from its Common Market partners and others than it received to reduce its deficit in 1963 or than the United Kingdom and the United States received to reduce their deficits. This is true in spite of the fact that the surplus of Italy, relative to its trade and to its domestic economy, was far larger than the deficits of either Britain or the United States; and it exceeded the large British deficit of 1964 in absolute size.

Ideally, responsibility for adjustment between deficit and surplus countries should be divided according to some world welfare criteria, but we have no such criteria. Indeed, there has been no serious explicit discussion of them in official circles. I might make some partial remarks on that question, however, particularly in light of Emminger's assertion that during the last five or six years the burden of adjustment has fallen very one-sidedly on the surplus countries. This assertion raises both a factual question and an analytical one. Many private U.S. firms and government agencies would cer- tainly be surprised to learn that they have borne very little burden as a result of the U.S. balance-of-payments program. But at a more general level, the United States did take deflationary measures in the severe budget of 1959, largely as a result of balance-of-payments considerations. The Kennedy administration was basically out of sympathy with that approach, but it nonetheless refrained from reflating as rapidly as might have been possible. Balance-of-payments considerations - and public attitudes toward "gold losses"-played a major role in the caution with which the administration moved toward more aggressive economic expansion. As a result, the United States lost more than $\$ 150$ billion worth of output during this period, a loss that exceeds by 50 per cent the entire annual output of Germany, which is the second largest economy in the non-Communist world.

The analytical question concerns what exactly we mean by "burden of adjustment." Many Europeans feel very strongly about inflation; and inflation is politically important for that reason alone. But that is not the same as saying inflation was or is a great "burden" in economic terms. The burden of creeping inflation is yet to be demonstrated in analytical terms, ${ }^{1}$ and indeed there are those who even go so far as to argue that moderate inflation is beneficial, not detrimental. Even if we leave that argument to one side, it is particularly questionable whether recent inflation in Europe has been a great burden, since much of the upward adjustment in costs there has not been reflected in higher prices. ${ }^{2}$ Past savings have

1 Tibor and Anne Scitovsky (1964) have examined the possible costs of creeping inflation in the United States and conclude it is very small compared with the costs of underemployment.

2 I dismiss the steady but moderate increases in consumer price indexes for this purpose. These indexes do not reflect improvements in quality and they contain a heavy component of wages, so they naturally increase as real economic growth proceeds, leading to higher factor incomes. Japan offers the outstanding illustration, with its steady improvement in international cost competitiveness accom- 
not been arbitrarily appropriated to any great extent through inflation. Rather, inflation has shifted the distribution of income. This obviously represents a cost to some segments of society, but it is a benefit to others; and without some explicit judgment about who should get what it is difficult to say whether European countries have been made worse off or better off as a result of their experience during the last five years. In contrast to inflation, unemployment imposes a heavy cost on some segments of society with no corresponding benefits to others. Whatever economic cost one might attribute to European inflation, it certainly cannot come close to the lost output in the United States.

Regardless of the outcome of this cost comparison, we are not likely to get internationally the same kind of payments adjustment which we now have interregionally within each country. This is in part because industrial nations are simply unwilling to tolerate the same level of inflation or of unemployment and idle resources which regions within a country are willing to tolerate. It is in part because no large stock of universally acceptable financial assets exists to be passed around from one country to another, and residents of surplus countries are either unable or unwilling to lend extensively to deficit countries through private channels. Most countries, indeed, are not willing to give up monetary policy as an instrument of domestic policy, a necessity if international lending is to be the main source of "adjustment." And it is in part because governments of surplus countries are not willing to offer the same long-term finance-even grants-to deficit countries that surplus regions within a country are willing to grant to deficit regions within a country. A New Yorker can identify to some extent-even here it has often been difficult

panied by increases in the "cost of living" of more than 5 per cent per annum since 1960. European commodity prices have risen far less than the rise in unit labor costs, and in some cases have fallen. -with the plight of the West Virginian. The Welshman or Breton or Sicilian is just too remote to call forth any substantial finance of a long-term character. ${ }^{3}$

Under these circumstances, and so long as we desire to maintain the existing structure of exchange rates, we must recognize that restrictions ${ }^{4}$ on international payments will become more common and, indeed, an essential feature of the adjustment process. For most countries restrictions are far less costly in terms of lost output than is deflation, resulting as the latter does in idle capacity and unacceptable levels of unemployment. (It is not clear whether restrictions are more or less costly in economic terms than is inflation.) If we are to rely more heavily on restrictions-Emminger suggests the need for restrictions on capital account, but they might also have to be extended to current account-we should search for ways to minimize the adverse effects of such restrictions and to confine their motivation and use as much as possible to requirements of the balance of payments. What forms are least damaging to efficiency and to the freedom of international transactions? And how can the use of such restrictions be kept within acceptable bounds? Answers to the first question may vary from country to country. (For a given improvement in the balance of payments, restrictions probably do more damage to a relatively open economy than to a relatively closed one.) They should have to be justified on balance of payments grounds and should require some form of international approval to avoid self-defeating retaliation. And, as Emminger says, it is far preferable where possible to avoid restrictions by the deficit countries altogether by having the surplus countries liberalize their payments instead.

\footnotetext{
${ }^{3}$ The Marshall Plan was an outstanding exception, and recently within the EEC some lending to depressed areas has taken place through the European Investment Bank.

${ }^{4}$ Defined to include tax measures and even voluntary restraint programs, not merely direct controls.
} 


\title{
REFERENCES
}

Scitovsky, Tibor and Anne. "Inflation versus Unemployment: An Examination of Their Effects," in Joseph Conard et al. Inflation, Growth, and Employment. Englewood Cliffs,
N.J.: Prentice-Hall, Inc., for the Commission on Money and Credit, 1964.

Tinbergen, J. On the Theory of Economic Policy. Amsterdam: North-Holland Publishing Co., 1952.

\section{COMMENT: THE OBLIGATIONS OF SURPLUS COUNTRIES}

\author{
RAYMOND F. MIKESELL \\ University of Oregon
}

\begin{abstract}
$\mathrm{U}$ NDER conditions which have prevailed over the last several years in which a principal reserve currency country is in continual deficit while several non-reserve currency countries have experienced what they regard as unwanted surpluses, what are the obligations of the surplus countries in the balance of payments adjustment process? In considering this question, it should be observed that non-reserve currency countries have certain options which are not available to the United States if it is to properly exercise its function as world banker. For example, the United States cannot devalue without an almost simultaneous adjustment of the gold parities in most of the countries of the world. It cannot or should not impose capital controls which impair its operation as world banker, and it has an obligation not only to its domestic economy but to the rest of the world not to deliberately deflate at the cost of substantial unemployment, a lower rate of growth, or a sharp diminution or cessation of capital exports. The latter point is particlarly important, since the United States has an obligation not just to the handful of surplus countries that do not want additional reserves but to the majority of the countries of the world not in this favored position. Deflationary action and reducing capital exports by the United States would impair the ability of deficit countries to adjust their balance without reducing output.
\end{abstract}

The fact that non-reserve currency countries have a wide range of options whether in surplus or deficit does seem to impose certain obligations upon them in the adjustment process. They are after all beneficiaries of an orderly international financial system which can only be maintained through cooperative action. First of all, surplus countries have an obligation to co-operate in freeing international trade and to remove their restrictions on capital exports. Certain large surplus countries, including France, continue to maintain capital export controls. Surplus countries also have an obligation to maintain a mix of monetary and fiscal policies which will discourage large capital imports and perhaps encourage capital outflow. Finally, if these measures do not suffice in eliminating unwanted surpluses, they have the option of currency appreciation. They also have the option of controlling capital imports, but this would appear to be a second-best solution.

While there are certain costs associated with currency appreciation, appreciation on the part of a few reluctant surplus countries is easier than having the United States together with most of the rest of the world depreciate vis-à-vis the surplus countries. Depreciation is almost inevitably inflationary since it is virtually impossible to balance increases in prices of international goods with decreases in prices of domestic goods without sacrificing employment and output. 